\title{
IMPLEMENTING E-LEARNING THROUGH SOCIAL MEDIA IN ISLAMIC UNIVERSITIES DURING PANDEMIC
}

\author{
Anwar Hafidzi ${ }^{1}$ dan Rimayanti ${ }^{2}$ \\ Universitas Islam Negeri Antasari, Banjarmasin, Kalimantan Selatan, Indonesia \\ Email: ${ }^{1}$ anwar.hafidzi@gmail.com; ${ }^{2}$ rimayanti@uin-antasari.ac.id
}

\begin{abstract}
This research explores the use of E-learning in many universities in Southern Kalimantan in Indonesia in the Covid-19 pandemic against students. Although some researchers study e-learning during a pandemic, researchers concentrate more on the quality of e-learning than in a classroom. This study is a quantitative field research with an online learning survey methodology and its effect on student readiness. This study shows that $80 \%$ of students are not prepared to completely engage in online learning unless they use the combined form of learning. Sixty percent of students agree that finance is the key part of online quota-based learning, while 25 percent of students do not care about the economy. This results in a trend which is only used by smartphones with a high per capita income. The findings also run counter to the goal of e-learning, which makes learning less efficient. This is attributable to students being unprepared to face the latest online learning standard.
\end{abstract}

Keywords: Implementation, e-learning, social media, universities, pandemic.

\section{Introduction}

The spread of Coronavirus or severe acute respiratory syndrome coronavirus 2 (SARS-CoV-2) in all parts of the world including Indonesia is a virus that attacks the respiratory system (Dong, Du, \& Gardner, 2020). The disease due to a viral infection is called Covid-19. Coronavirus can cause disorders of the respiratory system, acute pneumonia, until death. The impact that emerged from this pandemic also resulted in various kinds of obstacles in the world of education and the economy in general (Rothan \& Byrareddy, 2020).

During the coronavirus epidemic, people flocked to purchase an excessive number of masks and hand sanitizers. Indeed, in many countries affected by coronavirus, the panic buying trend is, of course, expensive and rare in medical preventive tools for coronavirus (Nicola et al., 2020). In providing information the spread of this virus is even dominated by the 
media (Abdulkarim, Ratmaningsih, \& Anggraini, 2018). Each media platform which is delivered may contain several different information. However, information from reputable and dubious sources, depending on the medium that is deemed to help the user, does not display the correct trend of presenting information. Some were in the end deceived by unclear reporting, some followed. The consequence is a shutdown of all operations, including schooling, in different countries.

Indonesians are very panicked by the virus Covid-19, even in Southern Kalimantan. The government appeals and the Indonesian Ulama Council appeal for the abolition of the schools, campuses and offices including congregational prayers were removed (Bai et al., 2020). In Indonesia, the number of positive Coronavirus cases continues to increase. The cure rate continues to increase, however.

The addition of positive cases COVID-19 in Indonesia can be seen on the covid19.go.id website and submitted directly by the Government Spokesperson regarding Handling of Covid-19, Achmad Yurianto. Until Friday $(6 / 5 / 2020)$, there were 29,521 positive cases. Of these, 9,443 patients were declared cured and 1,770 people died. While the place to be studied, namely in the province of South Kalimantan, of course also began to increase as well. recorded confirmation was Positive For 1,213 people, 104 patients recovered, and 93 died. These data were updated daily with cut-off data at 12.00 WIB.

Based on the statistics and of the rising effects of Covid-19 this considered a plague. This includes problems in the education system linked to increasingly urgent economic needs. The impact of the Coronavirus pandemic has now begun to spread to the world of education in the education system (Yue et al., 2020). The Central Government until the Regional Government has issued a policy of dismissing all educational institutions. This was done as an effort to prevent the spread of Coronavirus. Initially, the spread of the Corona virus was very important in the slow- 
moving economy but now the field of education has also had an influence (Fernandes, 2020). The policies adopted by many countries, including Indonesia by removing all educational activities, make it necessary for the government and the related institutions to present alternatives for students who cannot carry out the education process in educational institutions as an educational process.

The Pandemic of Covid-19 caused a significant decline in the economic conditions in many countries in the world, not only for third world countries but the superpower economies also experienced, even to a certain degree worse than poor countries and countries developing (Khan \& Faisal, 2020). Based on World Bank predictions, the majority of countries in the world are expected to experience a recession with economic growth in the range of $1 \%$ even minus during the third quarter of 2020 and will continue the following year if the outbreak is not over (Sumner, Hoy, \& Ortiz-Juarez, 2020). This condition certainly forces people to make savings, cut all unnecessary expenses to reduce the portion of the budget for primary needs, including education.

The education sector is no longer using the old pattern of face-to-face learning methods. During the pandemic Covid-19, e-learning-based methods became a method that must be used at all levels of education in Indonesia, bearing in mind that this epidemic requires humans to keep their distance and limit direct interaction (Rusdiana, Suryana, Hidayat, \& Mu'in, 2020). Different methods are employed to keep the education system and the Community economy stable, but the Indonesian government's willingness to use electronic or online systems, particularly in Indonesia's South Kalimantan province, is considered to be additional burdensome on the economy in the region.

Until now, in Indonesia, many campuses have been using existing online applications such as Edmodo, Google Classroom, Zoom, etc. to introduce teaching and learning policies and online lectures (Putri, Hamuddin, 
Nursafira, \& Derin, 2020). The government and its scenario just want to stay at home with several goals that are willing to work together to encourage students to learn online. However, the effect is seen in several studies that often influence the physical immune system and the environment, which increase the intensity of stress and weakness. The amount of rough work ends and the economic struggle of a range of workers is becoming more and more difficult (Hur \& Im, 2013). These problems will continue to grow if different approaches are not stopped so that everything can be performed well without sacrifice.

The advantages of this research can at least answer that this pandemic of Covid-19 can stress people with new habits and have an impact on the destruction of the education system and the economy with the new system in the new normal order. Although different from the opinion, which says that the new order can make the education system and the economy to be as normal as the beginning with the model.

\section{Research Methods}

This research is a quantitative area of research with a survey approach to online learning and its effect on student preparation. Researchers have tried to use the views of students at many universities in South Kalimantan, Indonesia. This survey was conducted to assess the influence of online and media-focused learning. Other impacts include comprehension, emphasis on learning, efficacy, and factors that help or do not support online learning readiness.

The population in this study were students of Islamic Religious Colleges \& Universities (PTKI) in South Kalimantan Province. The reason for population selection is because demographically, many PTKI students come from remote areas that are still difficult in terms of access to electricity and internet infrastructure, besides that in terms of economic capability many come from underprivileged families, so it is felt necessary to conduct 
research related to obstacles economics in online learning during the pandemic Covid-19.

The sample in this study were state and private PTKI students, namely Antasari State Islamic University in Banjarmasin, Al-Falah Islamic High School in Banjarbaru, Kalimantan Islamic University Sheikh Muhammad Arsyad al-Banjari Banjarmasin, Rakha Amuntai Islamic High School in Amuntai, and Barabai Islamic High School in Barabai. The research sample is 100 people who have been participating since 2017 in universities. This study took place between February until July 2020. The data analysis in this study uses descriptive quantitative methods, in order to obtain an overview of the economic barriers to social media-based e-learning during the Covid19 epidemic, where the results of the questionnaire are analyzed.

\section{Results and Discussions}

\section{Media Between Learning or Depression Attitudes}

The creation of different learning media is in line with the rapid advances in technology. The current technological dynamics are attaining extraordinary acceleration. The technology developed many years ago has begun to be replaced by new technologies including different traditional methods of learning (Amoutzopoulos et al., 2018). To use e-learning is the form of development of information technology which can be used as a learning medium. E-learning is an advancement that can be used in the learning process, not only in the delivery of learning material but also in the ability of different student competencies. Students not only listen to educators' content explanations through e-learning but also constantly observe, perform, illustrate and so on. Teaching content should be visualized in different ways , making it more engaging and complex so that students can be inspired to go forward in the learning process (Favale, Soro, Trevisan, Drago, \& Mellia, 2020). 
E-learning means ICT, which helps students to study whenever and whenever they are. Different terms are used to express views/ ideas on elearning, including e-learning, or web-based learning. The model of elearning, based on information technology, leads to changes in learning culture in the learning context (Sakarji et al., 2019). But what if all levels of education did this? And 4 to 7 hours a day every day with the use of a not small internet quota. This would obviously have a positive negative effect on students who engage in online learning.

The Microsoft Power Point, Macromedia Flash, video, and other types of software can be utilized. Such applications may be used in many exact, social and religious educational materials, so that a instructor is capable of organizing the applications according to the specifications and goals of the content and learning to be accomplished. This learning technique will then have some effect (Klašnja-Milićević, Ivanović, Vesin, \& Budimac, 2018), including the opportunity to improve students ' ability to learn and understand in the field of information and technology. Save time and productivity because most are copied and save paper to learn more effectively. Exchanging thoughts with teachers is better as it relies more on the online board. Or it can help students learn independently from the other online platforms to grasp different lessons in lectures.

Whereas the negative effects are increasingly uncommon from one student to the other, unless the findings are seen on a smartphone or on a computer. This will also influence the evaluation produced since learning or just knowledge is difficult to distinguish. It cannot then calculate its capacity correctly. The most dangerous thing about the development of boredom in learning that results in online or depression in education (Lee \& Oh, 2017).

E-learning adds to the students' mental burden. This is the main factor. The mental burden is defined as a person's cognitive capacity in the face of a specific task. In the meantime, the mental burden they are experiencing will be automated when someone feels their workload exceeds the cognitive 
capacity. Especially for people with economic disabilities. Psychological and psychological readiness to influence e-learning and social media while this pandemic is certainly necessary. The relationship between resource unpreparedness and economy determines the on-line system of education in several Universities in Indonesia, particularly in the South of Kalimantan province.

\section{Support For Online Learning Financial Capacity And Infrastructure}

In connection with efforts to minimize transmission and transmission rates of coronaviruses, guidelines to research at home have been provided by the government since March 2020. The circumstances were entirely online for teachers, schoolteachers as well as students who had studied with a faceto - face and structured learning program. It's been happening long, but it has not been clear until now how much time each student's home is provided by the online school system (Lee \& Oh, 2017).

In fact, there are benefits and disadvantages, or the study of psychologists, the online learning system and the school which is currently being undertaken during the COVID-19 pandemic. For students as well as teachers, parents, colleges, and educational stakeholders (Hafidzi, 2020). Indeed, online lectures are 'forced' at tertiary institutions due to terms that do not allow personal lectures. Naturally, teachers and students will respond very differently. Some people are happy to welcome you, some heavily. Likewise, for university leader, especially the Quality Institute. A lecture process should be able to meet the requirements defined and even exceed them. It will be difficult to ensure their quality with online lectures that are not yet sponsored by infrastructure, expertise, materials and learning tools and various other aspects.

Many students in Indonesia may complain about these online lectures from several meetings in general, including: 
a. It doesn't take a small quota, when the lecture takes place every day. If it takes about 4-6 hours a day every day it can be expected a month, it will take about 120 Gigabyte if the active time per day requires 2 Gigabyte. Although many apps are used in face-to - face active lectures, such as zoom, google meetings or other media. When calculated with an Internet connection in Indonesia, the quota required is not cheap. A good economy is then required to fulfill the duties and functions of the government's learning. Not to mention other urgent needs.

b. During this pandemic, the biggest challenge during online learning was the consistency of the Internet. Not every student has good internet connections in areas. So, it would be hard for many students to complain of poor networks that have been experienced when teachers teach online when learning online would not be uncommon for them. The effects of poor network quality make the voices of lecturers unclear in their explanatory material and intermittent videos, often causing students to miss the lectures provided by the instructor. Of course, the learning system will be disturbed.

c. It appears boredom because only the screen is set. When lockdown takes place, lecturing policies are concentrated and segregated at home and influence self-sufficiency. Tired eyes on your computer affect selfsaturation and mind, which prevents students from coping well to learning.

If achieved quickly and considered to be unable, all desires are likely to be difficult to fulfill. If the Indonesian government wants to apply the learning system online, it seems to have to look at several aspects. Can be seen from the quality aspect and infrastructure supporting factors. Otherwise, this would be like a boomerang afflicting the current education system, all of which are failures. 


\section{Data and Analysis Results}

Implementation of the e-learning learning model in developing countries incidentally still does not have learning support as good as in developed countries. Based on research results, there are many variants of obstacles that can affect the application of e-learning, including the lack of experience and ability in implementing e-learning technologies that have not yet developed, and funding problems (Gewald \& Jacob, 2013). Research by Ahlan, Atanda, \& Shehu (2014) which focuses on obstacles in implementing elearning in developing countries conducted in Nigeria found that the problem of infrastructure availability is the main problem faced as a result of low economic growth and uneven economic development. The infrastructure includes the absence and fluctuation of electricity supply, ownership \& availability of computers, internet access, frequency of internet usage, and computer mastery competencies of e-learning learners. In addition to the factors above, many other factors can influence the implementation of elearning. The following is a summary of the various obstacles that can affect e-learning based learning by Esterhuyse (Esterhuyse \& Scholtz, 2015).

The threat of a global economic recession caused the education budget is also reduced. This is certainly a new problem considering the e-learning method through social media requires stable financial support to ensure the effectiveness of the teaching and learning process. This study tries to explore the economic obstacles in implementing e-learning through social media. The indicators used are the development of indicators by Esterhuyse and Scholtz (2015) with modifications according to conditions in the field that focus on economic factors and indicators regarding the use of social media in elearning which consists of 5 constructs: perception of usability, perceptions regarding ease of use, usage behavior, and accessibility to social media-based e-learning learning systems (Al-Rahmi et al., 2020).

Based on the survey results of respondents' responses to the effectiveness of online learning during the Covid-19 pandemic in South 
Kalimantan Province of Indonesia, most respondents considered that online learning was not effective. This can be seen from the graph, where most respondents (more than 50\%) expressed doubt, were ineffective or even ineffective. This means that most students find it difficult to do online learning, although it has been supported using technology, not all courses can be conveyed properly so that it affects the effectiveness of online learning.

Regarding the impact of online learning, respondents' response graphs also showed responses that were not much different from before, where more than half of respondents $(58,3 \%)$ stated that online learning actually had a negative impact and even had no impact at all for students. This certainly needs to be a concern, especially those involved in online learning activities, because if it turns out that online learning has no impact or even has a negative impact, then a careful evaluation of learning material, learning methods, and principals must be carried out learning, in order to achieve learning objectives

Based on the survey results regarding the ability of the resources owned by respondents to the internet quota that will be used in online learning, it appears that all respondents have sufficient resources to provide internet quota (37.1\%) and have adequate support to ensure the sustainability of the internet resources, including namely the financial support of parents or family as much as $33.2 \%$. All respondents were able to make sure that internet access is always available regularly, either by buying quotas or installing a private Wi-Fi network (8.8\%), besides that they also have sufficient financial capacity so that they do not need financial assistance from other parties in the form of loans or debt (20.8\%).

In connection with the ownership of smartphone facilities to support online learning activities, almost all respondents (97.5\%) stated that the smartphone that was in their possession was private property. This means that there will not be many obstacles when learning online because as a personal property the smartphone is not bound by usage time or type of use 
(can be used at any time and for any purpose). However, it should also be noted that there are still a small number of students who do not yet have smartphone facilities as private property. They get smartphones by leasing $(0.4 \%)$ or borrowing from other parties $(2.8 \%)$ during online learning activities.

Indeed online learning activities do not absolutely have to use a smartphone, can also use a laptop or desktop PC media, but for students who live not in big cities, will be a little difficult if you have to use a laptop or desktop Computer when studying online, because they have to work on a network Wi-Fi or providing a LAN network, which is difficult given the telecommunications infrastructure in South Kalimantan is not as good as in Java. Therefore, the use of smartphones as a means of online learning is still the main choice because the provision of internet access is enough to buy pulse or quota at a dealer near their place of residence.

Regarding the use of social media in e-learning, more than half of respondents (64.2\%) consider that learning online through social media makes it easier for them to find information \& references. Given the rapid spread of information on social media it is not surprising that it is very easy to find information there, even events that just happened a few seconds ago can quickly spread to different parts of the world thanks to the speed of information technology. Meanwhile, 28\% of respondents stated that the existence of e-learning learning methods using social media made them more productive in terms of expressing their opinions and more critical of the material being taught. Not all students have the courage and confidence to express opinions in front of class in front of their peers and lecturers, so that when studying online where there is no face-to-face meeting, they find the courage to ask questions and express ideas/ criticisms in class online.

Based on the results of a survey of respondents, it appears that many students $(83.5 \%)$ consider that the use of social media as online learning media is an interesting idea to apply. Considering that students are in the 
young age range, they are very familiar with social media, so that there are almost no significant difficulties for them to be able to use social media as a learning tool. From the beginning only as a means of entertainment, along with the development of innovative learning techniques, social media can also be used as a learning tool. While there are $16.5 \%$ of respondents who disagree with the use of social media as a means of learning online, this is given in the social media platform there are a lot of content that can disturb or distract students from learning material, so they assume that online learning through social media is not a good idea because the true function of social media is for entertainment.

\section{CONCLUSION}

Based on the survey results, most respondents did not experience economic obstacles in the social media-based online learning process. They have enough financial support, and can provide technological devices (smartphones, internet quotas) to be able to access online learning activities on an ongoing basis. The perception of most respondents regarding the use of social media for online learning activities is generally good. But contrary to the positive response, the perception of the effectiveness of online learning turned out to be unsatisfactory for most respondents. This is reasonable considering that the application of online learning methods is still relatively new in the Province of South Kalimantan. This is what might cause most students to be unfamiliar with online learning methods.

The implication of this research is that pure online education has not been able to learn what is considered "new". Blended learning models are easier to understand in current and future learning and educational systems. Maybe other researchers can examine the components of education at home, whether it is effective or still considered not finding good learning patterns. 


\section{REFERENCE}

Abdulkarim, A., Ratmaningsih, N., \& Anggraini, D. N. (2018). Developing Civicpedia as a Civic Education E-Learning Media To Improve Students' Information Literacy. Journal of Social Studies Education Research, 9(3), 45-61.

Ahlan, A., Atanda, B. N., \& Shehu, Y. I. (2014). Information technology enhances students' academic performance: A case of University of Ilorin. The Online Journal of Distance Education and E-Learning, 2(2), 15-20.

Al-Rahmi, W. M., Yahaya, N., Alturki, U., Alrobai, A., Aldraiweesh, A. A., Omar Alsayed, A., \& Kamin, Y. B. (2020). Social media-based collaborative learning: The effect on learning success with the moderating role of cyberstalking and cyberbullying. Interactive Learning Environments, $1-14$.

Amoutzopoulos, B., Steer, T., Roberts, C., Cade, J. E., Boushey, C. J., Collins, C. E., ... Van Rossum, C. (2018). Traditional methods v. new technologiesdilemmas for dietary assessment in large-scale nutrition surveys and studies: A report following an international panel discussion at the 9th International Conference on Diet and Activity Methods (ICDAM9), Brisbane, 3 September 2015. Journal of Nutritional Science, 7.

Bai, Y., Yao, L., Wei, T., Tian, F., Jin, D.-Y., Chen, L., \& Wang, M. (2020). Presumed asymptomatic carrier transmission of COVID-19. Jama, 323(14), 1406-1407.

Dong, E., Du, H., \& Gardner, L. (2020). An interactive web-based dashboard to track COVID-19 in real time. The Lancet Infectious Diseases, 20(5), 533-534.

Esterhuyse, M., \& Scholtz, B. (2015). Barriers to e-learning in a developing country: An explorative study. Proceedings of the 9th IDIA Conference.

Favale, T., Soro, F., Trevisan, M., Drago, I., \& Mellia, M. (2020). Campus traffic and e-Learning during COVID-19 pandemic. Computer Networks, 107290 .

Fernandes, N. (2020). Economic effects of coronavirus outbreak (COVID-19) on the world economy. Available at SSRN 3557504.

Gewald, H., \& Jacob, O. (2013). Pre-adoption motives for successful eLearning: A case study of socially deprived users in South Africa. 2013 Africon, 1-5. IEEE.

Hafidzi, A. (2020). Cultural Education As An Effort To Prevent ReligiousBased Radicalism On Social Media In Indonesia. Potret Pemikiran, 24(1), 58-70.

Hur, M. H., \& Im, Y. (2013). The influence of e-learning on individual and collective empowerment in the public sector: An empirical study of Korean government employees. The International Review of Research in Open and Distributed Learning, 14(4). doi: 10.19173/irrodl. v14i4.1498 
Khan, N., \& Faisal, S. (2020). Epidemiology of Corona virus in the world and its effects on the China economy. Available at SSRN 3548292.

Klašnja-Milićević, A., Ivanović, M., Vesin, B., \& Budimac, Z. (2018). Enhancing e-learning systems with personalized recommendation based on collaborative tagging techniques. Applied Intelligence, 48(6), 15191535.

Lee, S. M., \& Oh, Y. (2017). The Mediator Role of Perceived Stress in the Relationship between Academic Stress and Depressive Symptoms among E-learning Students with Visual Impairments. Journal of Visual Impairment \& Blindness, 111(2), 123-134. doi: 10.1177/0145482X1711100204

Nicola, M., Alsafi, Z., Sohrabi, C., Kerwan, A., Al-Jabir, A., Iosifidis, C., ... Agha, R. (2020). The socio-economic implications of the coronavirus and COVID-19 pandemic: A review. International Journal of Surgery.

Putri, S. E., Hamuddin, B., Nursafira, M. S., \& Derin, T. (2020). Discourse Analysis in E-Learning-Based Course Using Moodle Platform: An Experimental Design. REiLA: Journal of Research and Innovation in Language, 2(1).

Rothan, H. A., \& Byrareddy, S. N. (2020). The epidemiology and pathogenesis of coronavirus disease (COVID-19) outbreak. Journal of Autoimmunity, 102433.

Rusdiana, A., Suryana, Y., Hidayat, A., \& Mu'in, A. (2020). POE2WE Learning Management Based on Google Classroom Blended Learning (Alternative Models in Learning during WFH Pandemic Covid-19). International Journal of Psychosocial Rehabilitation, 24(08), 49945005.

Sakarji, S. R., Nor, K. B. M., Razali, M. M., Talib, N., Ahmad, N., \& Saferdin, W. A. A. W. M. (2019). Investigating Students Acceptance Of E-Learning Using Technology Acceptance Model Among Diploma In Office Management And Technology Students At Uitm Melaka. Journal of Information, 4(13), 13-26.

Sumner, A., Hoy, C., \& Ortiz-Juarez, E. (2020). Estimates of the Impact of COVID-19 on Global Poverty. UNU-WIDER, April, 800-9.

Yue, X.-G., Shao, X.-F., Li, R. Y. M., Crabbe, M. J. C., Mi, L., Hu, S., ... Dong, K. (2020). Risk Prediction and Assessment: Duration, Infections, and Death Toll of the COVID-19 and Its Impact on China's Economy. Journal of Risk and Financial Management, 13(4), 66. 